\title{
Ian Cummins
}

\section{Senior Lecturer in Social Work}

\section{University of Salford}

i.d.cummins@,salford.ac.uk 


\title{
Social Work and the era of the penal state
}

\begin{abstract}
The Criminal Justice System (CJS) has historically been a key site of social work intervention. Wacquant $(2008,2009$ a and 2009b) argues that the growth of social insecurity and the expansion of the penal state are endogenous features of the neo-liberal political project. The key premises of neo-liberalism have been accepted by parties of both the left and the right. Wacquant identifies that the "doxa" of the penal state such as "prison works" "zero tolerance" and "broken windows" have been widely accepted in an uncritical fashion. This shift alongside an increase in inequality had led to increasing social anxiety and mistrust. One manifestation of these trends is the "decline of the rehabilitative ideal" (Garland, 2001). Offenders, who were once generally viewed as marginalised individuals in need of social and welfare support are now regarded as sites of risk. The USA has led a penal arms race, in which, the use of imprisonment has grown significantly. In Europe, England and Wales has followed this trend most closely. Whilst acknowledging that penal policy is the result of a complex inter-relationship between social, cultural and historical factors, there are lessons to be learnt from the US experience. These include the impact of race and class inequalities as manifest in the CJS. The act of imprisonment is arguably an act of state violence and alongside the impact on individuals, communities and families, it has huge symbolic significance and value. The expansion of the penal state: the increasing numbers, poor conditions and the over-representation of minority groups mean that it should be a core social work concern. The paper outlines the ways, in which, risk and managerialism have sidelined core social work values in the CJS. It concludes that developments in the USA, particularly the decision in Brown v. Plata highlight a way out of the current impasse. Penal policy and conditions can only be reformed if the inherent dignity of offenders is rediscovered and placed at its centre.
\end{abstract}

Key words: criminal justice, neo-liberalism, offenders, buman rights, social justice

\section{Introduction}

This paper will argue that internationally the Criminal Justice System (CJS) should remain a key site of social work intervention and broader concern for the academy. The expansion of the use of imprisonment has been a feature of public policy across a number of jurisdictions. The USA 
has led the way in this penal arms race. There are now over two million people in US jails; the country that has five per cent of the world's population has over twenty-five per cent of the world's prisoners. In Europe, England and Wales have followed this trend most closely. This paper argues that the increase in the use of imprisonment is the result of an increase in wider social inequality. As Wilkinson and Pickett (2010) propose, one of the effects of inequality is the breakdown in social bonds and increased mistrust between citizens. Garland (2004) suggests that increased punitivism reflects broader "othering" of social groups - in this case the marginalised urban poor and those from minority communities. Less contact between social groups makes for scapegoating and the production of feelings of alienation. The approach, here, is influenced by Bauman's (1989) analysis of the Holocaust. Modern approaches to punishment and broader penal policy create an image of the offender as an alien - someone who is not one of us. This dehumanising process allows for such individuals to be treated with indifference or worst contempt.

Wacquant $(2008,2009$ a, 2009b) argues that the use of mass imprisonment is an endogenous feature of neo-liberalism. In Becker's (1968) model, offenders are making a rational choice to commit crime. Possible punishment or other sanctions are part of a cost benefit analysis that offenders make. This position has, in many areas, overtaken a more traditional welfare approach, which sees the roots of offending in personal and social circumstances. As Garrett (2015) argues crime is now seen as the result of lack of individual and social control. The response is therefore one of increased surveillance of citizens and communities. In some countries social work as a profession has curiously retreated from the Criminal Justice System (CJS) just as the expansion of the penal state was at its strongest. Yet, the use of imprisonment and prison conditions should be of great concern to social work practitioners, educators and the academy. There are clear areas for relevance for social work such as; the wider social and economic damage that imprisonment does to marginalised communities, the inhuman and degrading treatment that is a feature of overcrowded prison systems and the experiences of women and minorities within these regimes. Social work's broader commitment to social justice means that it has a role on an individual and organisational level in tackling these issues.

\section{The development of mass incarceration}

A number of terms have been used to describe the expansion of the use of imprisonment: mass incarceration, mass imprisonment, the prison boom, the carceral state or the penal state. These terms refer to the phenomenon of the rise in the use of penal sanctions and a time when crime rates have been falling. The USA has led the way in this penal arms race. As a consequence much of the analysis
Commented [CM1]: Is it really an 'arms race'? Can you find a better description? 'Advancement of the penal state'? 
of this punitive turn has been carried out there. However, the issues of the expansion of imprisonment, the conditions in prisons and the impact of increased imprisonment rates on already poor and marginalised communities should be key concerns for social work wherever it occurs. The expansion of the use of imprisonment has been a feature of a number of jurisdictions. Simon (2014) has compared the expansion of the use of imprisonment to a biblical flood, a flood that he now sees as past its peak and identifies three elements of phases in the development of mass incarceration. Driven by a fear of crime and the political fallout from being seen as weak on the issues (Simon, 2007), prosecutors ask for custodial sentences where previously a community penalty would have been imposed. Then sentences are increased - the war on drugs is an example of this process. Finally, mandatory and or indeterminate sentences are introduced. The standard comparative measure for imprisonment is the rate per 100, 000 of the population. Since 1999, the overall world prison population rate has increased from 136 per 100, 000 to 144 per 100, 000. The USA remains at the top of this incarceration league with a rate of 716 per 100,000. This overall average hides huge disparities between individual states. Carson and Golinelli (2013)'s analysis shows that the five states with highest imprisonment rates: Louisiana $(1,720)$, Mississippi $(1,370)$ Alabama $(1,234)$ Oklahoma $(1,178)$ and Texas $(1,121)$ have rates well above the national average.

The impact of imprisonment is not restricted to the individuals involved. There is a significant body of research that demonstrates the wider damage that has been done to the AfricanAmerican community (Mauer, 2006, Clear, 2007 and Drucker, 2011). The damage does not end when individuals are released. Many US states prevent ex-prisoners from voting, accessing social housing or completing educational programmes. Alexander (2010) powerfully argues that the overall effect serves to create a new "caste" of disenfranchised and marginalised young black men. Wacquant (2009) argues that the USA can be viewed as a laboratory and that a nexus of think tanks and prominent individuals such as Bill Bratton, a former LAPD and NYPD Commissioner, have facilitated the spread of these penal policies.

In Europe, the UK has been the country that has most closely followed the USA in its race to incarcerate. The statistics are astonishing; particularly when one considers that in the early 1970s some sociologists were predicting the end of the prison as an institution. Walmsley (2013) provides a detailed analysis of rates of imprisonment across the world. As he notes, there are 
now 10.2 million people who are held in penal institutions. Nearly a quarter of these prisoners 2.4 million are in prison in the USA. Along with Russia (0.68 million) and China (1.64 million), the USA holds nearly half the world's prisoners. Walmsley (2103) concludes that prison populations have been growing across all five continents over the past fifteen years of the publication of the World Prison Population List. The expansion of the use of imprisonment, the past 20 years have seen the increased privatisation of sections of the CJS. This is the logical extension of applying market mechanisms to the provision of services. In Australia and the UK where privatization has expanded rapidly, companies such as G4S have been given lucrative contracts to manage immigration detention centres and the electronic tagging of offenders.

Wacquant (2009) shows the ways, in which, the "prison industry" has become a key factor in local employment, particularly in rural areas. The attraction being that for employees the prison provides secure relatively well-paid jobs with benefits such as health insurance that are not widely available in generally impoverished communities. This creates a vicious circle where any reduction in the rate of imprisonment will be seen as economic threat, which contributes to political pressure at a local and national level.

Lacey (2008) warns against the dangers of making comparisons between penal regimes that ignore the wider cultural forces that contribute to the development of the cultures that underpin them. For example, she suggests that liberal market economies with the concomitant deeply engrained individualism have become more punitive. The USA is, of course, the prime example of this. However, as noted above, there are very significant variations between the states. When exploring penal policy, it is impossible to ignore the role of historical, social and other factors. In examining the European experiences of the expansion of imprisonment, Lacey's warning is important. Calvadino and Dignan (2006) in their analysis of penal policies and the use of imprisonment developed a political economy typology - neo-liberal, conservative -corporatist, social democratic and oriental corporatist. Examples of all these, apart from oriental corporatist exist within Europe and the European Union.

Walmsley (2013) provides detailed information on the rates of imprisonment across the European Union. The Baltic States have the highest rates of imprisonment. One might expect that these rates would decline as the shift toward democracy is strengthened and civil society becomes more established. Other local factors need to be considered, for example, Portugal's liberalisation of drug laws has led to a reduction in the use of imprisonment. The UK, Spain and France are examples of countries where the use of imprisonment has been on an upward curve
Commented [CM4]: Now in its $11^{\text {th }}$ edition (Walmsley, 2015, http://www.prisonstudies.org/sites/default/files/resources/downlo ads/world_prison_population_list_11th_edition.pdf

Commented [CM5]: $Z$ or s but be consistent 
and seems set to continue in that fashion. Germany and Holland are notable as countries where the use of imprisonment has fallen. Subramanian and Shames (2013) show that this is due to policies such as the concentrated use of community penalties and suspended sentences in both countries. Downes and Hansen's (2006) analysis of eighteen countries including the UK and USA concluded that there was a clear relationship between welfare provision and penal policy: the lower the spending on welfare, the higher the rate of imprisonment.

Pratt (2008) argued the case for Scandinavian exceptionalism in penal policy. The features of this are the very low rates of imprisonment as illustrated below but also the good physical conditions in these institutions. Researchers were struck by the personal space that prisoners had and the relatively good material conditions that they were afforded. All prisoners were working or studying full-time. If they were in open prisons then they were able to remain in their employment. There have been criticisms of the Swedish welfare state. For example, Barker (2012) observes that the Swedish welfare state is a great achievement but only if you are seen as belonging to it. It has an implicit exclusionary character and there are tremendous social pressures to conform. The Nordic model has come under increasing pressure with the rise of right wing anti-immigration parties (The Guardian June 2015) and, as with similar populist parties across Europe, crime and welfare are issues that they seek to exploit. 


\section{Penal narratives}

Common sense or widely held views are "not expressed in theoretical terms" rather they are spread by images, stories and myths (Taylor, 2003). The increase in the use of imprisonment in the USA and the UK has been driven by an often racialised image of the offender as a young, strong psychically fit male. The message being that such individuals pose a general threat to the wider populace. Even though, it is widely accepted that crime rates are falling, the meme that Simon (2007) describes as Governing through Crime - a combination of fear of crime, law and order having a much more powerful impact on the wider political debate and a general public disillusion with alternative to imprisonment - remains very powerful. One of the most powerful of Hall et al's (2013) insights into the nature of state power is the fact that violence and the need to respond to it generate a very strong support for its wider use. Many commentators have made this link post 9/11, and Hall et al show that the early 1970s crises such as the UK response to Irish nationalist terrorism had similar impacts; for example, the targeting and demonizing of minority communities and the introduction of legislation that restricted civil liberties. One potential role for social work as a profession is to challenge and counteract these narratives. There is an increasingly significant body of research (Tyler , 2013, Slater, 2009 and 2012, Jensen, 2013 ) which examines the ways, in which, an underclass eugenicist discourse has become deeply embedded in popular and political discourse but also the impact of this on poor, marginalised individuals and communities with whom social workers often interact. This work largely focuses on the experience of women in either poorly paid precarious work or in receipt of welfare. An analysis of mass incarceration needs to be carried out alongside this work to present a full picture of the impact of the retreat of the social state and to help inform a more explicit counter narrative that social work can embrace.

The Trencin Statement (2007) which outlines the UN position on the treatment of prisoners states that

"Prisoners shall have access to the health services available in the country without discrimination on the grounds of their legal situation.

(www.euro.it/en/bealth)

The 2013-14 report from HM Inspector of Prisons in England and Wales paints a very disturbing portrait of the current prison regime. The Chief Inspector report showed there was a 69\% rise in suicides in a prison in 2013-14. He described it as "the most unacceptable feature" of a prison system that is experiencing a "rapid deterioration" in safety standards. The report paints a 
portrait of prisons where bullying, violence - including sexual violence - and intimidation are commonplace. It also indicates that drugs are widely available while there is often little constructive activity for prisoners in overcrowded institutions.

At its worst, overcrowding meant two prisoners sharing a six foot by ten foot cell designed for one, with bunks along one wall, a table and chair for one, some shelves, a small TV, an unscreened toilet at the foot of the bunks, little ventilation and a sheet as a makeshift curtain.

A few prisoners might spend 23 hours a day in such a cell. Twenty bours was relatively common in a local prison. Prisoners would eat most of their meals in their cell. The food budget was reduced from £2.20 per prisoner per day in 2012 to $£ 1.96$ a day in 2013.

The prison population is overwhelmingly drawn from the most marginalized communities. This is reflected in both the physical and mental health care of offenders. As the Royal College of Nursing (RCN) (2004) outline, there is a higher incidence of long term conditions and chronic disease amongst the offender population compared to the general population. These conditions include coronary heart disease, diabetes, mental health issues, substance misuse and HIV. Those groups in society who face the greatest barriers or are less likely to access health care in the community - young men / sex workers/IV drug users - are also much more likely to be incarcerated. The problems outlined above are exacerbated by overcrowding which is a consistent feature of the wider use of imprisonment. For example the WHO (http://www.who.int/tb/challenges/prisons/en/) reports that the rate of TB is estimated to be 100 times higher in the prison than the general population. Overcrowding, poor nutrition, late diagnosis, poor treatment and transfer of prisoners contribute to the spread of the disease. In addition, as the Trencin statement makes clear, prisoners are entitled to the same level of healthcare as their fellow citizens. Catching TB should not be seen as one of the risks of being imprisoned - it is not part of the sentence. The conditions that help TB flourish are not limited to developing nations.

Throughout the world, women are incarcerated at lower rates than men but this is rising; since 2000 the global female prison population has risen by 50\% (Walmsley, 2013; 2015). This is largely explained by the gender differences in crime rates - women commit less crime than men. The Corston Inquiry (2007) was set up to look at the issues that arise from the imprisonment of women in England and Wales. The Inquiry was established following a rise in cases of suicide and self-harm. Women are much less likely to commit violent or other serious offences than 
men meaning that they are more likely to be sentenced to shorter periods in custody. One impact of the smaller numbers of women in custody is that there are fewer female prisons. Women are thus more likely to be sent to a jail further from their local community, with subsequent impacts on maintaining family links and future reintegration. The Inquiry gives a stark outline of the wider factors in the lives of the women in custody: $37 \%$ - attempted suicide at some time in their life,

$51 \%$ have severe and enduring mental illness, over 50\% had been subjected to domestic abuse and one in three had been sexually abused. In addition, it is important to consider the impact on children. As the Howard League report (2010) children are the forgotten victims of escalating incarceration. The perceived interests of justice can appear to override the rights of the children involved to live with their parents. Apart from the anxiety generated by separation in such circumstances, there is a huge dislocation in children's lives. This may lead to them having to take on new familial or caring responsibilities.

The decline of Social Work in the CJS: the case of England and Wales

The recent history of the Probation Service in England and Wales reflects decline of the belief in rehabilitation and reform (Garland 2001). It has moved from a "social work agency in the CJS" focusing on tackling the social problems that were seen as being as the root cause of offending to a risk management agency. With the introduction of Community Rehabilitation Companies (CRC) these reforms almost totally sever the link between probation and its social work roots. CRCs will supervise 160,000 offenders who are deemed to be a medium to low-risk whilst the National Probation Service will retain responsibility for high-risk offenders. The economics are fairly clear here: contracts for the supervision of low-risk offenders are much more attractive to companies as the costs will be lower. A Public Accounts Committee (PAC) report by British MPs concludes, the timetable for the introduction of these complex changes has not allowed for the new arrangements to be fully piloted. These reforms follow a pattern of other welfare reforms elsewhere in the world where private companies have been given large contracts to deliver services. Cadavino et al (1999) coined the term "punitive manageralism" to describe the shifts that had occurred within UK penal policy outlined above. In the face of persistently high crime rates, official research has shifted from the social causes of crime to an emphasis on crime prevention and the management of individual offenders (Gregory, 2007).

Beckett and Western (2001) argue that wider social policy is inextricably linked with developments in penal policy. In their analysis, political cultures that emphasize social causes of 
marginality and offending are much more likely to have a penal policy based on integration. The result will be lower rates of imprisonment. At the other end of this continuum, cultures that conceptualise social problems largely as the result of individual failings, will lead to harsher views on crime and thus higher rates of imprisonment. Wilkinson (2000) concludes that a culture, such as the USA, where competitive individualism, is a deeply embedded cultural trope will see offenders as unreformable. Furthermore, Tonry (1999) argues that more inclusive cultures also provide a protection against the sorts of moral panics that occur in response to individual high profile crimes or offending. In support, Green (2008) contrasts the media and legal responses two cases of child murder by children. The murder of Jamie Bulger by two ten year old boys in England is consistently constructed as symptomatic of a wider and deep-seated moral decline. On the other hand, the murder of Silje Redergård in Trondheim, Norway was seen as tragic oneoff where the perpetrators require expert ongoing intervention with the ultimate aim of their reintegration into society. However, in line with global trends, Barry and Leonardsen (2012) argue that there is a danger of making very broad judgements on the basis of these two exceptional cases and go on to suggest that it is possible to identify increasing punitive trends within the Norwegian system.

\section{Rediscovering Dignity: A way forward}

Foucault's (1977) Discipline and Punish: The Birth of the Prison opens with a description of the punishments inflicted on the attempted regicide by Damiens, which are outlined in great detail. To the modern reader, these appear as examples of brutality. Nietzsche in On the Genealogy of Morality (trans. Clark and Swensen 1998) had concerned himself with the development of social mores. He saw this as a way in which man's elemental impulses were contained. Nietzsche outlines the most gruesome of Old German punishments. These included: stoning, boiling in oil or wine and smearing the transgressor with honey and leaving him to bake in the sun. The most prominent feature of these punishments is their physical brutality. Nietzsche and Foucault do not approach such punishments as simple outbursts of savagery. Punishment is a regulated cultural practice. The physical nature of the punishment reflects the belief that crime was considered an offence against the monarch. This is not just the case for Damiens but all offenders. The symbols and rituals of punishment reflect the value system of the society that produces it. In this process, Foucault notes that the offender is allowed to denounce the judges before the sentence is carried out. In this way, the established order is over turned for a moment before being restored and reinvigorated by the punishment. 
Foucault (1977) contrasts the image of Damiens being pulled apart by horses, having been subjected to a litany of assaults including having molten wax poured on him, with the sombre image of Foucher's prison timetable. For Foucault, this is a paradigmatic shift. The timetable represents the Enlightenment values of rationality. He argues that from the French Revolution onwards punishment as a public spectacle declined. As the definition of what constituted a crime remained largely unchanged this shift, Foucault argues, can only be explained by moves in societal values. This does not represent progress but a rather a shift in the ways that social control and domination are exercised. For Foucault, the key feature of the penal or psychiatric system was the struggle of the individual against the wider societal impulses to conform or control. Thus the changes in penal policy he discusses are the beginnings of new technologies of power rather than elements of a humanitarian project to reform brutal regimes. Mass incarceration has as its aim the incapacitation of offenders. One feature of the expansion of the penal state has been overcrowded prisons. This, along with populist moves to make regimes more Spartan, amount to a reversal of the shift that Foucault outlined (Foucault, 1977, 2008). The body of the offender has once again become the site of punishment. Examples of this shift would include the recent ban on books being sent to prisoners in England and Wales or the activities of Arizona Sheriff Joe Arpaio. Arpaio prides himself on forcing offenders to wear pink underwear and sleep in tents in the baking local heat as well as boasting of spending more on food for prison dogs than inmates.

The USA has led the way in the expansion of the use of imprisonment resulting in a huge prison industrial complex that marginalizes even further the most disadvantaged urban communities particularly African- American ones (Drucker , 2011; Garland, 2001; Gottschalk, 2006; Mauer, 2006; Wacquant, 2009; Alexander, 2010). What Simon (2014) has termed the "arc of punitiveness" began in the mid-1970s driven by populist response to increases in violent crime and the politicization of the law and order debate (Simon, 2007). The USA is an outlier in this field but the use of imprisonment has increased across Europe with England and Wales most closely following the US trends. The US experience can act as a warning of the potential social and communal damage that a policy of mass imprisonment can inflict. In particular, the impact on already poor and marginalized communities. It might be tempting from a European perspective to ignore these developments or see them solely as a result of the US history - in particular slavery. I would argue that this is a mistake. Race is clearly an issue - it is not one that just 
applies in the US. In the UK, African- Caribbean citizens are imprisoned at a rate of 6.8 per 1000 compared to 1.3 per 1000 amongst white citizens. $27 \%$ of the UK prison population comes from a Black Minority Ethnic background and over two thirds of that group are serving sentences of over four years (1990 Trust, 2010). Berman (2012) reports that in June 2011 13.4\% of the prison population, where ethnicity was recorded was Black or Black British. This group comprises $2.7 \%$ of the general population. It is estimated that $70 \%$ of the French prison population is Muslim - the figure in the general population is $8 \%$. It is illegal to collect figures on ethnic background in France so no official statistics exist. It is also an issue of class as the overwhelming majority of prisoners live in poverty. Wacquant (2009) has used the term "antighetto" to describe stigmatised areas - urban housing estates or the banlieues in France. Those living in these areas are either in precarious work or reliant on some form of welfare. The term "anti-ghetto" captures the idea that these areas and their citizens are stigmatized but the social bonds of the racialized ghetto are missing. These are also the areas that most social and community work is carried out - either by statutory or voluntary agencies.

Nelken (2006) cautions against using Garland's (2001) notion of a "culture of control” in a simplistic or reductionist fashion arguing that there are multiple cultures of control. However, it is clear that within these cultures the general shifts from seeing the CJS as a site of possible social work intervention to viewing it as risk management processing system are well established. In the UK, a key factor was the decision in 1997 to introduce a new Diploma in Probation Studies (Gregory, 2007). Under the new Diploma, probation officers no longer trained with social work students. As Gregory (2010) notes the term probation officer was subsequently replaced by a new one "offender manager" - a term that almost sums the decline of the rehabilitative ideal and its replacement by a form of actuarial risk management. In the academy, it has become more difficult to find discussion of the impact of mass imprisonment in the social work literature. For example, neither the European Journal of Social Work nor the British Journal of Social Work has published an article in this field in the past year, which has specifically addressed the impact of imprisonment on individuals or communities. The focus of social work debate has been on children and families social work with little or no reference to the incarceration of mothers and fathers. This is not to argue that the issues covered are not important. However, there is a major issue of social justice with significant implications for the most disadvantaged communities in society. It is an issue that social workers encounter in their day to day practice, responding to the needs of children separated from their parents, whilst leaving the wider issue of social injustice to others. An important question raised by this analysis is whether they can do otherwise, or 
whether the parallel individualization of child welfare in this context amounts to consent to unjust social practices (Tyler, 2013).

The four countries of the United Kingdom have very different legal systems. One feature of this is the approach to offending. In the Scottish system, social work has maintained a key role in penal policy. I would suggest that it offers a model for an approach that can re-establish social work in this area. Scotland's $21^{\text {st }}$ Century Social Work Review Group proposes that

\section{"Reducing re-offending is essentially concerned with the achievement of positive change in the lives of offenders"}

This statement is based on a welfare approach that recognizes that reducing offending, which is the only way to increase public protection, has to be based on an approach that promotes the social inclusion of offenders. The promotion of social inclusion is one of the key tasks and skills of social workers. Social workers can achieve this by building positive relationships with offenders. This is essentially a call for a strengthening of the social work approach and an end to managerialism and bureaucratic practice. It would be naïve to assume that such a change will occur overnight. Punitive approaches remain very popular and deeply entrenched in public discourse. One of the roles for social work as a profession is to challenge effectively what Wacquant (2009) terms the "doxa" of neo-liberal penality - manifest in empty slogans such as zero tolerance and prison works. It can do this from a position of moral and empirical strength.

Simon (2014: p1) likens the increase in use if imprisonment to a biblical flood that is now beginning to recede. The rate of imprisonment now appears to be stabilizing but it remains very high. It seems therefore somewhat counterintuitive to look to the USA - the home of the penal state for a solution to the problems that mass incarceration creates. In Brown $v$. Plata a group of prisoners successfully sued the state of California arguing that the state's penal policies, the overcrowding that they produced and the resultant inadequate healthcare, amounted to a breach of the $8^{\mathrm{TH}}$ amendment constitutional prohibition of cruel and unusual punishment. As noted above, the healthcare needs of prisoners are far greater than those of the wider community. These are exacerbated by imprisonment. The inevitable result of imprisoning more people for longer was the collapse of a prison healthcare system. There are echoes of these issues in the most recent report from the HM Inspector of Prisons in England and Wales. Justice Kennedy who wrote the majority decision in Brown v. Plata was so appalled by the conditions that existed that he included photographs in the Supreme Court Judgment. This was the first time that this had happened. The photographs are a representation of the human impact of the penal crisis in 
California These include scenes of chronic overcrowding and "dry cells" essentially cages used for holding cells for people waiting for transfer to mental health facilities.

Justice Kennedy concluded "prisoners retain the essence of human dignity ... A prison that deprives prisoners of basic sustenance, including adequate medical care, is incompatible with the concept of buman dignity and has no place in a civilized society". The idea of dignity can be a starting point for the transformation of the CJS. The development of a policy of mass incarceration has occurred at a time when recorded crime rates have generally been on the decline. However, the use of imprisonment, despite the manifest evidence of its failure remains deeply entrenched in public policy. There are, however, grounds for a more optimistic view and hopes that social work and social work values can play a more constructive role. The features are both economic and sociopolitical. The crash of 2008 has led to retrenchment in public spending including on imprisonment. It is an irony that one of the consequences of the crash might be a rebalancing of the CJS with an emphasis on community punishments as alternatives to imprisonment. The fact that the motivation for this is fiscal rather than philosophical does not make it any less welcome. In Governing through Crime, Simon identified several key features that drove the politicization of penal policy. These included the fear of violent crime and the war on drugs. As violent crime rates decline then there is less potency or a law of diminishing returns in political calls to tackle them. This is not to say that law and order does not remain a very important political and policy issue. It does acknowledge that if a society or community feels safer then there is less scope to exploit the issue politically. The war on drugs - i.e. a harsh punitive response to those involved in any way with using or dealing illegal narcotics - is now widely accepted to be a failure (Gray 2001, Levy-Pounds 2013). The Drug Policy Alliance (2011) analysis of media reporting shows that this failure has been acknowledged around the world. The appeal of harm reduction strategies and a response to substance misuse that is informed by public health principles will have an inevitable impact on reducing prison numbers. In addition, to be sustained, war requires propaganda and the demonizing of an enemy. These processes become much harder to sustain if recreational drug use is more common.

In 1990, response to a previous crisis in the prison system in England and Wales led to prison riots, including one at Strangeways Prison in Manchester. The Strangeways riot was the longest in UK penal history and a public inquiry (Woolf, 1990) was conducted. The riots were a response to overcrowding and the poor conditions in prisons including the practice of "slopping out" where prisoners had to use a bucket as a toilet and empty them out each morning. The practice 
was abolished in England as late as 1995. It should be noted that the prison population, at that time of the riots, was less than half what it is now. The Woolf Report (1991) was seen as a blue print for an improved prison system. The Home Office developed policies to reduce imprisonment on the basis that "prison is an expensive way of making bad people worse." These liberal moves were abandoned under subsequent governments committed to the idea that "prison works" (Gottschalk, 2006).

It is indicative of the current crisis that Lord Wolff has written the foreword to a recent report Presumption Against Imprisonment that calls for a radical rethink in penal policy. As Woolf argues

Imprisonment should not be the default sentence handed down. We should instead seek to develop a clear framework for identifying the kinds of case in which imprisonment will be the appropriate sentence.

\section{http://www.britac.ac.uk/policy/Presumption Against Imprisonment.cfm}

To achieve this, the report recommends using diversion from the courts more extensively; promoting greater use of alternative forms of sentence; prohibiting or restricting the imposition of short custodial sentences; removing or restricting the sanction of imprisonment for certain offences; reviewing sentence lengths; and removing mentally disordered and addicted persons from prisons. Such policies chime with core social work values and are based on an implicit recognition of the inherent dignity of individuals. They also focus on the social causes of offending. There is an underlying emphasis on welfare solutions that has the potential to begin to unpick what Wacquant (2009) terms prisonfare.

The above analysis of current trends in penal policy and the potential that they create for a reengagement of social work with the CJS, is influenced by Stuart Hall's revival of the term, from Marx and Gramsci, of conjuncture. Conjuncture, is simply a combination of events.

However, Hall uses it as a tool for the analysis of the current political and cultural trends. Hall was seeking to move away from the rigid economic determinism of Marxism and argues that it is important to consider cultural developments. An economic analysis, Hall suggests, only takes one so far (Cummins, 2014). Thus the economic will impact on penal policy in that it will be seen as too expensive but also the cultural can play a role. If social attitudes to the use of drugs change as they have, it becomes more difficult to create a "war on drugs". A shift, which sees drug use as essentially an issue of health, will lead to a more social welfare based response. This 
creates possibilities for social workers alongside health and social care professions more generally. Throughout the past thirty years, individual workers within the CJS have carved out creative spaces where they can continue to practice in a way that has more in common with notions of rehabilitation than risk management. These processes are very much in their early stages. Such developments are not linear. Of course, it is possible that this analysis is overoptimistic or that any progress will be derailed by a moral panic around a high profile crime or crimes. However, there is a role for individual social workers, academics and the wider profession to influence penal policy. The CJS should be a key area of concern for the profession and the academy. Social work needs to forcefully make the case that imprisonment fails on its own terms and has a devastating impact on individuals, families and communities. Rediscovering notions of dignity and developing policies based upon it are the place to start. Scottish policy in this field provides some clear directions for future policy development. 


\section{References}

Alexander, M (2012) The New Jim Crow; Mass Incarceration in the Age of Colorblindness New York .New Press

Barry, M and Leonardsen, D (2012) Inequality and Punitivism in Late Modern Societies: Scandinavian Exceptionalism Revisited European Journal of Probation vol 4(2) pp46-61

Bauman, Z (1989) Modernity and the Holocaust Ithaca, New York Cornell University Press.

Beckett, K and Western, B (2001) Governing Social Marginality on D. Garland, ed. Mass Imprisonment: Social Causes and Consequences London: Sage 35-50

Becker, G (1968) Crime and Punishment: An Economic Approach Journal of Political Economy 76 526-536

Berman, G (2012). Prison Population Statistics: House of Commons Library.

British Academy (2014) A Presumption Against Imprisonment www.britac.uk

Carson, E and Golinelli, D (2013) Prisoners in 2012: Trends in Admissions and Releases 1991-2013 www.bjs.gov/content/pub/pdf/p12tar9112.pdf

Cavadino, M., Crow, I. and Dignan, J. (1999) Criminal Justice 2000, Reading, Waterside Press.

Cavadino, M. and J. Dignan (with others) (2006) Penal Systems: A Comparative Approach. London: Sage Publications.

Clear, T (2009) Imprisoning Communities: How Mass Incarceration Makes Disadvantaged Neighborhoods Worse. New York. OUP

Corston, J (Chair) (2007) Review of Women with Particular Vulnerabilities in the Criminal Justice System London HMSO

Downes, D and Hansen, K (2006) Welfare and Punishment www.crimeandsociety.org.uk

Drucker, E (2011) A Plagues of Prisons; The Epidemiology of Mass Incarceration in America New York. New Press 
Drug Policy Alliance (2011) Drug Policy Alliance and Global Commission on Drug Policy June 2011

Media Report www.drugpolicy.org.

Feeley, M., \& Simon, J. (1994). Actuarial justice: The emerging new criminal law. In D. Nelken (Ed), The Futures of Criminology (pp. 173-201). London: Sage

Foucault, M. (1977): Discipline and Punish (translation A. Sheridan). London: Penguin

Foucault, M (2008) The Birth of Biopolitics: Lectures at the Collège de France. 1978- 1979, trans.

Graham Burchell. Basingstoke. Palgrave

Garland, D (2001) The Culture of Control Crime and Social Order in Contemporary Society Oxford. OUP

Garland (2004) Beyond the Culture of Control Critical Review of International and Political Philosophy Vol 7 (2) 160-189

Garrett, P (2013) Social Work and Social Theory Making Connections. Bristol. Policy Press

Garrett, P (2015) Confronting neoliberal penality: Placing prison reform and critical criminology at the core of social work's social justice agenda Journal of Social Work

Gray, JP (2001) Why our drug laws have failed and what can we do about it: a judicial indictment of the War on Drugs. Philadelphia: Temple University Press: 2001.

The Guardian (http://www.theguardian.com/news/datablog/2015/jun/19/rightwing-antiimmigration-parties-nordic-countries-denmark-sweden-finland-norway accessed 19.7.2015

Green, D. A. (2008) When Children Kill Children: Penal Populism and Political Culture. Oxford. OUP

Gregory, M. (2007) Newly qualified probation officers talk about their training, Social

Work Education, 26(1), pp. 53-68.

Gregory, M (2010) Reflection and Resistance: Probation Practice and the Ethic of Care British Journal of Social Work. 40, 2274-2290

Howard League (2010) Voice of a Child http:// wmw. howardleague.org

Jensen, T (2013) Riots, Restraint and the New Cultural Politics of Wanting Sociological Research Online, 18 (4) 7 
Lacey, N (2008): The Prisoners' Dilemma: Political Economy and Punishment in Contemporary Democracies. Cambridge. Cambridge University Press.

Levy -Pounds (2010) Can these bones liv? A look at the impacts of the war on drugs on poor African - American Children and Families Hastings Race and Poverty Law Journal 353-380

Nelken, D. (2006) Comparative Criminal Justice: Beyond Ethnocentrism and Relativism European Journal of Criminology 6(4) 291-311

Mauer, M (2006) The Race to Incarcerate. New York. New Press

Nietzsche, F. (1996) on the genealogy of morals: a polemic: by way of clarification and supplement to my last book, Beyond good and evil; translated with an introduction and notes by Douglas Smith. Oxford. OUP

Pratt, J (2008a) Scandinavian Exceptionalism in an Era of Penal Excess Part I: The Nature and Roots of Scandinavian Exceptionalism Br J Criminology 48 (3):119-137

Pratt, J ( 2008b) Scandinavian Exceptionalism in an Era of Penal Excess Part II: Does Scandinavian Exceptionalism Have a Future? Br J Criminology 48 (3): 275-292

RCN (2004) Health and nursing care in the criminal justice service www.rcn.org.uk

Simon, J (2007) Governing Through Crime How the War on Crime Transformed American Democracy and Created a Culture of Fear. Oxford. OUP

Simon, J (2014) Mass Incarceration on Trial: A Remarkable Court Decision and the Future of Prisons in America New York, The New Press,

Simon, J (forthcoming) The Cruelty of Abolitionists

Slater, T. (2009) 'Ghettos' and 'Anti-urbanism' Entries in R. Kitchin and N. Thrift (eds) The International Encyclopaedia of Human Geography. London. Elsevier

Slater, T (2012) The Myth of "Broken Britain": Welfare Reform and the Production of Ignorance.Antipode Vol 0 p1-22

Subramanian, R and Shames, A (2013) Sentencing and Prison Practices in Germany and the Netherlands: Implications for the United States. New York, NY: Vera Institute of Justice

Taylor, C (2003) Modern Social Imaginaries Durham NC Duke University Press 
Tyler, I (2013) Revolting Subjects Social Abjection and Resistance in Neoliberal Britain. London. Zed Books

Tonry, M (1999) Why are US incarceration rates so high? Crime and Delinquency 45 419-437

Wacquant, L (2008) Urban Outcasts: A Comparative Sociology of Advanced Marginality

Cambridge. Polity Press

Wacquant, L (2009) Prisons of Poverty Minneapolis. UM Press

Wacquant, L (2009) Punishing the Poor The Neoliberal Government of Social Insecurity

Durham. Duke University Press

Walmsley, R (2013) World Female Imprisonment List

http://www.prisonstudies.org/sites/prisonstudies.org/files/resources/downloads/wfil 2nd edi tion.pdf

Weidenfeld and Nicholson

WHO (2007) Trencin Statement www.euro.it/en/health

WHO (2013) TB and Prisons WHO Global Report 2013 http://wnw.who.int/tb/challenges/prisons/en/

Wilkinson, R (2000) Mind the Gap: Hierarchies, Health and Human Evolution. London:

Wilkinson, R and Pickett, K (2010) The Spirit Level: Why Equality is Better for Everyone London.

Penguin

Woolf, Lord Justice Prison Disturbances April 1990: Report of an Inquiry, February 1991 Cm 1456

1990 Trust (2010). The Price of Race Inequality: The Black Manifesto. London: 1990trust.org.uk.

Legal Cases

Brown v. Plata http://www.supremecourt.gov/opinions/10pdf/09-1233.pdf 